\title{
Endoscopic gastritis, serum pepsinogen assay, and Helicobacter pylori infection
}

\author{
Sun-Young Lee
}

Department of Internal Medicine, Konkuk University School of Medicine, Seoul, Korea

Received: May 8, 2016

Accepted: August 8, 2016

\section{Correspondence to}

Sun-Young Lee, M.D.

Department of Internal Medicine, Konkuk University School of Medicine, 120 Neungdong-ro, Gwangjin-gu, Seoul 05030, Korea Tel: +82-2-2030-7747

Fax: +82-2-2030-7748

E-mail: sunyoung@kuh.ac.kr
Endoscopic findings of the background gastric mucosa are important in the Helicobacter pylori-seroprevalent population. It is strongly correlated not only with the risk of gastric cancer, but also with the excretion ability of gastric mucosa cells. In noninfected subjects, common endoscopic findings are regular arrangement of collecting venules, chronic superficial gastritis, and erosive gastritis. In cases of active $H$. pylori infection, nodularity on the antrum, hemorrhagic spots on the fundus, and thickened gastric folds are common endoscopic findings. The secreting ability of the gastric mucosa cells is usually intact in both noninfected and actively infected stomachs, and the intragastric condition becomes hyperacidic upon inflammation. Increased serum pepsinogen II concentration correlates well with active $H$. pylori infection, and also indicates an increased risk of diffuse-type gastric cancer. In chronic inactive $H$. pylori infection, metaplastic gastritis and atrophic gastritis extending from the antrum (closed-type chronic atrophic gastritis) toward the corpus (open-type chronic atrophic gastritis) are common endoscopic findings. The intragastric environment is hypoacidic and the risk of intestinal-type gastric cancer is increased in such conditions. Furthermore, there is a decrease in serum pepsinogen I concentration when the secreting ability of the gastric mucosa cells is damaged. Serologic and endoscopic changes that occur upon $\mathrm{H}$. pylori infection are important findings for estimating the secreting ability of the gastric mucosa cells, and could be applied for the secondary prevention of gastric cancer.

Keywords: Atrophy; Gastritis; Endoscopy; Helicobacter pylori; Pepsinogens

\section{INTRODUCTION}

Upper gastrointestinal (UGI) endoscopy enables physicians to estimate the secreting ability of gastric mucosa and gastric cancer risk based on the findings of the background gastric mucosa (Fig. 1). To measure the secreting ability of gastric mucosal cells, noninvasive serologic tests are preferred over invasive tube tests [1]. Noninvasive tests consist of the serum pepsinogen (PG) assay, calcium carbonate breath test, and hydrogen breath test, while invasive tests consist of aspiration tests (pentagas- trin and tetragastrin tests), endoscopic gastrin test, and intragastric $\mathrm{pH}$ measurements [2]. Recently, the serum PG assay has become preferred to the serum gastrin assay in measuring the status of the gastric mucosa, because gastrin is produced primarily by the endocrine $\mathrm{G}$ cells of the antrum $[3,4]$. A negative PG assay is indicative of healthy gastric mucosa with a negative predictive value of $>99 \%$ using serum PG I/II [5].

UGI endoscopy is performed biannually in Korea as a national screening system for secondary prevention of gastric cancer in all adults over 40 years of age. Never- 
theless, there is no standardized reporting format used to describe the findings of background gastric mucosa, and endoscopic gastritis is often underestimated during the screening process. This review article focuses on the

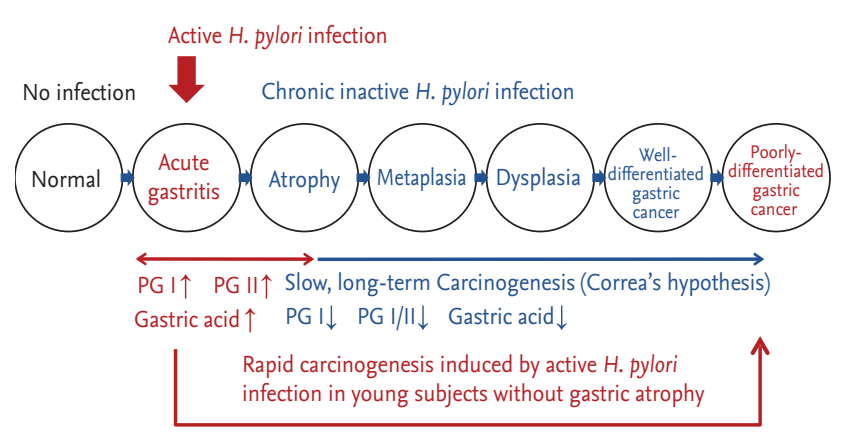

Figure 1. Endoscopic findings of the background gastric mucosa according to the gastric carcinogenesis pathway. Upon Helicobacter pylori infection, the gastric mucosa shows changes indicating active infection, such as multiple hemorrhagic spots, nodules, and thickening of the gastric rugae. During this stage, the risk of diffuse-type gastric cancer is increased, the intragastric environment becomes hyperacidic, and there is an increase in serum pepsinogen (PG) levels. When active inflammation subsides and the infection progress to a chronic stage, the background gastric mucosa shows atrophy and metaplasia. This long-term, slow process increases the risk of intestinal-type gastric cancer, the intragastric environment becomes hypoacidic, and there is a decrease in serum PG levels. endoscopic findings of the background gastric mucosa in conjunction with intragastric conditions as reflected by serum PG assay findings.

\section{INTACT STOMACH WITHOUT INFECTION}

The ability to secrete gastric acid and other gastric hormones is intact in subjects without $H$. pylori infection. The background gastric mucosa exhibits regular arrangements of the collecting venules when a subject has never been infected with $H$. pylori (Fig. 2). In hyperacidic conditions, multiple hyperemic erosions or linear streaks can occur on the antrum, which may lead to erosive gastritis (EG) or chronic superficial gastritis (CSG).

\section{Chronic superficial gastritis}

CSG is characterized by multiple linear streaks on the greater curvature side of the antrum. CSG is the most common endoscopic gastritis in Korea, followed by EG, chronic atrophic gastritis (CAG), and metaplastic gastritis (MG) [6]. Hyperemic streaks found in CSG do not require subsequent biopsy, since they are not associated with an increase in the risk of gastric cancer. CSG involves hyperacidic conditions. The secreting ability of

\section{Stomach without $H$. pylori infection}
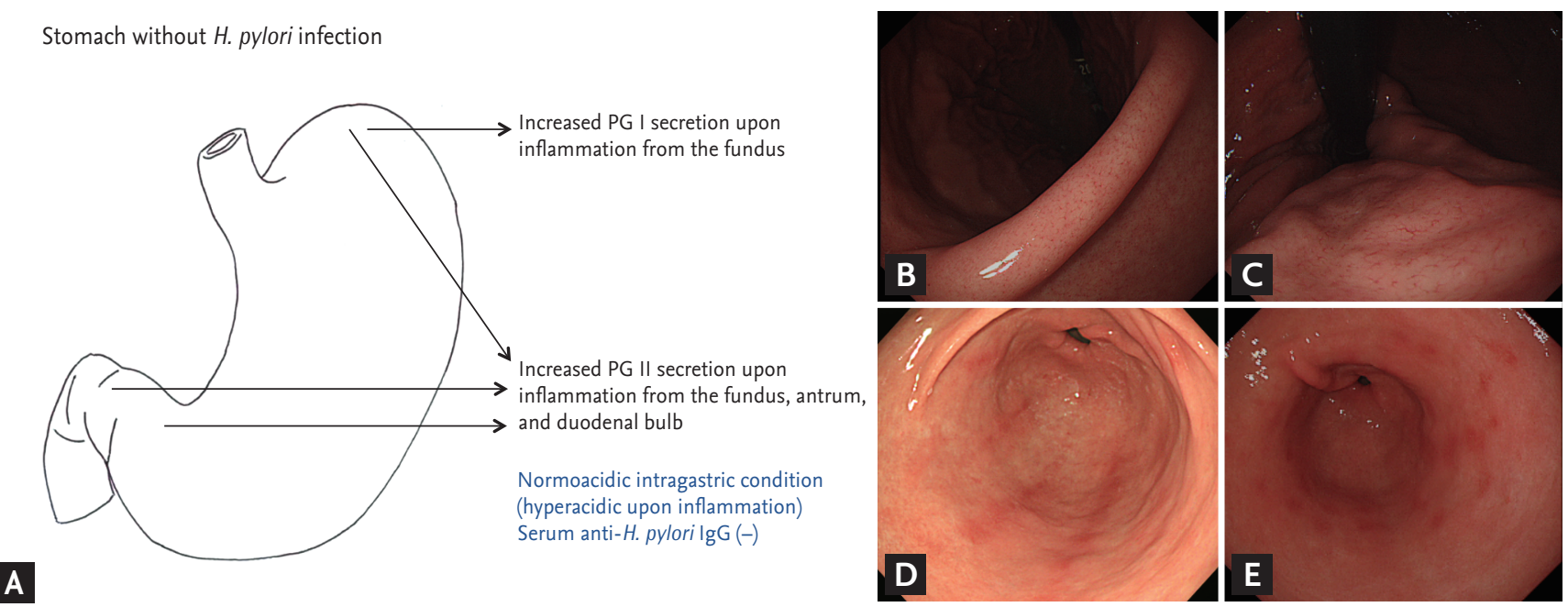

Figure 2. (A) Endoscopic findings in subjects without Helicobacter pylori infection. Pepsinogen (PG) I is produced exclusively by chief cells and mucus neck cells on the fundus. PG II is secreted throughout the stomach and also from the Brunner's gland of the duodenal bulb. (B) Normal endoscopic finding of the angle in noninfected subject. The regular arrangement of the collecting venules on the angle indicate normal gastric mucosa. (C) Normal finding of the corpus in the same subject. The regular arrangement of the collecting venules extends up to the on the cardia and fundus. (D) Chronic superficial gastritis. Several hyperemic streaks are noticed on greater curvature side of the antrum. (E) Erosive gastritis. Multiple raised, hyperemic erosions are visible on the antrum. 
the gastric mucosal cells remains intact.

\section{Erosive gastritis}

EG presents with multiple raised erosions with hyperemic changes on the antrum. Erosions can be found in both noninfected subjects and in subjects with active $H$. pylori infection (Table 1). In the absence of $H$. pylori infection, the incidence of gastric cancer is low [7]. In EG, the intragastric conditions are hyperacidic, and the secreting ability of the gastric mucosal cells remains intact.

\section{Other gastritis unrelated to $H$. pylori infection}

Endoscopic gastritis in noninfected individuals is rare areas with endemic $\mathrm{H}$. pylori infections. Type A autoimmune gastritis is an initially asymptomatic disease that progresses to corpus atrophy with pernicious adenoma (B12 deficiency) or iron deficiency anemia [8]. Granulomatous gastritis is related to Crohn's disease, tuberculosis, syphilis, sarcoidosis, anisakiasis, or reaction to a foreign body. Eosinophilic gastroenteritis presents with non-specific gastrointestinal symptoms, and may involve the esophagus or colon [9]. Others types of gastritis include collagenous gastritis, postradiation gastritis, and drug-related gastritis.

\section{STOMACH WITH ACTIVE H. PYLORI INFECTION}

Active or acute $H$. pylori infection can be diagnosed by a gastric mucosal biopsy. The pathology findings show infiltrations of mononuclear cells and polymorphonuclear neutrophils. Because of the lack of a single endoscopic finding that indicates $H$. pylori infection, serology assays are often used to verify the status of the gastric mucosa.

\section{Hemorrhagic spots, nodularity, and thickened gas- tric folds}

Typical endoscopic findings of acute $H$. pylori infection include hemorrhagic spots on the fundus and/or highbody, nodular gastritis, and hypertrophic gastric rugae (Fig. 3). The endoscopic findings of nodular gastritis are small, round, yellowish-white nodules that represent histological lymphoid follicles [10]. Endoscopic nodular

Table 1. Common endoscopic findings in an endemic area of Helicobacter pylori infection

\begin{tabular}{|c|c|c|c|c|c|c|}
\hline $\begin{array}{l}\text { Status of } \\
\text { H. pylori } \\
\text { infection }\end{array}$ & $\begin{array}{l}\text { Endoscopic } \\
\text { diagnosis }\end{array}$ & Gross findings & $\begin{array}{l}\text { Location of the } \\
\text { lesion }\end{array}$ & $\begin{array}{l}\text { Secreting } \\
\text { ability }\end{array}$ & $\begin{array}{l}\text { Intragastric } \\
\text { acidity }\end{array}$ & $\begin{array}{l}\text { Serum PG } \\
\text { assay } \\
\text { findings }\end{array}$ \\
\hline No infection & $\begin{array}{l}\text { Chronic superficial } \\
\text { gastritis }\end{array}$ & $\begin{array}{l}\text { Several hyperemic } \\
\text { streaks }\end{array}$ & $\begin{array}{l}\text { Antrum, greater } \\
\text { curvature side }\end{array}$ & Intact & Normoacidic & Normal \\
\hline $\begin{array}{l}\text { No correlation } \\
\text { with infection }\end{array}$ & Erosive gastritis & $\begin{array}{l}\text { Several hyperemic, } \\
\text { raised lesions }\end{array}$ & Antrum & Intact & Hyperacidic & Normal \\
\hline \multirow[t]{3}{*}{$\begin{array}{l}\text { Active } \\
\text { infection }\end{array}$} & Nodular gastritis & $\begin{array}{l}\text { Multiple tiny and regular } \\
\text { submucosal elevated lesions } \\
\text { without color change }\end{array}$ & $\begin{array}{l}\text { Antrum } \\
\text { extending } \\
\text { toward corpus }\end{array}$ & Intact & Hyperacidic & $\begin{array}{l}\text { Increased } \\
\text { serum PG II } \\
\text { level }\end{array}$ \\
\hline & $\begin{array}{l}\text { Hemorrhagic } \\
\text { spots }\end{array}$ & $\begin{array}{l}\text { Multiple tiny and regular } \\
\text { reddish spots }\end{array}$ & $\begin{array}{l}\text { Corpus (fundus } \\
\text { and high-body) }\end{array}$ & Intact & Hyperacidic & $\begin{array}{l}\text { Increased } \\
\text { serum PG II } \\
\text { level }\end{array}$ \\
\hline & $\begin{array}{l}\text { Hypertrophic } \\
\text { gastric rugae }\end{array}$ & $\begin{array}{l}\text { Several thickened rugae } \\
\text { with edematous change and } \\
\text { whitish, sticky secretions }\end{array}$ & Corpus & Intact & Hyperacidic & $\begin{array}{l}\text { Increased } \\
\text { serum PG II } \\
\text { level }\end{array}$ \\
\hline \multirow[t]{2}{*}{$\begin{array}{l}\text { Chronic } \\
\text { inactive } \\
\text { infection }\end{array}$} & $\begin{array}{l}\text { Chronic atrophic } \\
\text { gastritis }\end{array}$ & Visible transparent vessels & $\begin{array}{l}\text { Antrum, lesser } \\
\text { curvature side } \\
\text { toward corpus, } \\
\text { greater curvature } \\
\text { side }\end{array}$ & Impaired & Hypoacidic & $\begin{array}{l}\text { Decreased } \\
\text { serum PG I } \\
\text { level }\end{array}$ \\
\hline & $\begin{array}{l}\text { Metaplastic } \\
\text { gastritis }\end{array}$ & $\begin{array}{l}\text { Multiple large and irregular } \\
\text { whitish elevations }\end{array}$ & $\begin{array}{l}\text { Antrum } \\
\text { extending } \\
\text { toward corpus }\end{array}$ & Impaired & Hypoacidic & $\begin{array}{l}\text { Decreased } \\
\text { serum PG I } \\
\text { level }\end{array}$ \\
\hline
\end{tabular}

PG, pepsinogen. 
gastritis is more common at the antrum than the corpus in H. pylori infection.

\section{Increased secreting ability of the gastric mucosal cells}

The secreting ability of the gastric mucosal cells is still intact during active $H$. pylori infection. Therefore, increased PG or acid secretion may occur upon stimulation or inflammation. Intragastric $\mathrm{pH}$ levels correlate well with $H$. pylori density and severity of gastritis [11]. $H$. pylori-induced gastritis can be identified using serum PG levels, because PG II levels are increased and the PG $\mathrm{I} / \mathrm{II}$ ratio is decreased in patients with $\mathrm{H}$. pylori infection as compared with those without infection $[12,13]$. Serum PG II concentration is known to be more useful in predicting active $H$. pylori infection than is PG I concentration.

\section{Increased risk of diffuse-type gastric cancer}

Regardless of age, nodular gastritis increases the risk of gastric cancer [14]. Although the serum PG assay is known to be more useful for the screening of intestinal-type gastric cancer than diffuse-type gastric cancer, a high PG II level indicates an increased risk of diffuse-type gastric cancer [15-17]. Therefore, H. pylori erad- ication is highly recommended in this stage of active infection; cellular changes seem to be reversible before the gastric mucosal cells progress beyond the point of no return $[18,19]$.

\section{STOMACH WITH CHRONIC INACTIVE H. PYLORI INFECTION}

Chronic infection indicates an inactive $H$. pylori infection that produces atrophic changes with or without intestinal metaplasia (IM). MG is noticeable when the loss of glands in CAG evolves into IM, and open-type CAG is highly correlated with Cdx2 expression and MG [20]. Nonetheless, there are limitations to pathologic evaluation using gastric biopsy in cases of MG, because it is hard to define an optimal biopsy site that would allow for evaluation of the entire stomach [21,22].

\section{Decreased secreting ability of the gastric mucosal cells}

Decreased serum PG I levels, open-type CAG, and old age are predictors of a hypoacidic state during $\mathrm{H}$. pylori infection [23]. Once the normal gastric glands are replaced by irreversible fibrosis and IM, the gastric environment
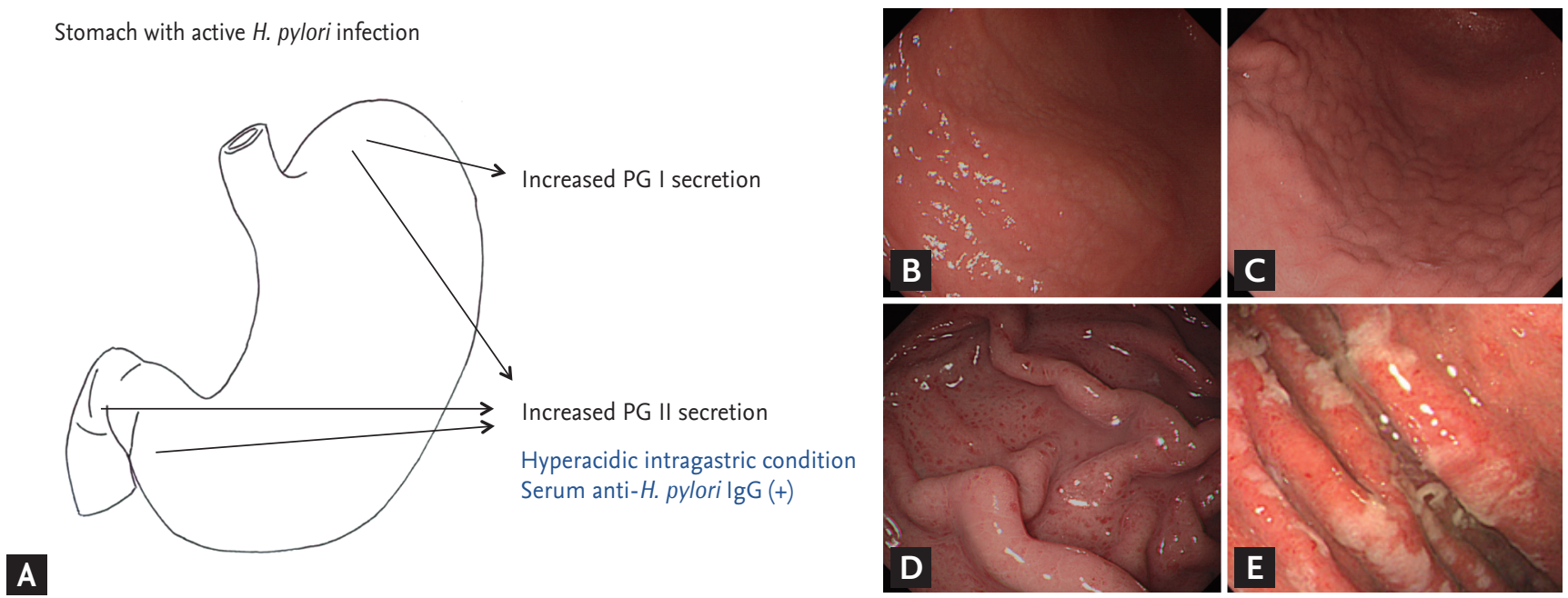

Figure 3. (A) Endoscopic findings in subjects with active Helicobacter pylori infection. (B) Nodular gastritis on the anterior-greater side of the proximal antrum. Multiple small nodules are visible on the antrum, extending up to greater curvature side of the corpus. The nodules consist of submucosal elevated lesions, and thus, there is no color change in nodular gastritis. (C) Follow-up findings of enlarged nodules on the proximal antrum to low-body in the same patient. The previously noted tiny, regular nodules have increased in size. The nodules were irregular and had grown from 12 months prior. (D) Finding of hemorrhagic spots on the fundus in nodular gastritis patient at initial endoscopy (B). Multiple tiny reddish spots, so-called diffuse redness, can be seen on the fundus and greater curvature side of the corpus. (E) Hypertrophic gastric folds. Thickened gastric rugae with whitish, sticky exudates indicate active $H$. pylori infection. PG, pepsinogen. 
becomes hypoacidic. For this reason, gastroesophageal reflux (GERD) is rare in subjects with CAG and/or MG [24]. Advanced endoscopic grading of atrophic gastritis is inversely associated with GERD.

\section{Gastric corpus atrophy as reflected by serum PG assay} Gastric corpus atrophy is defined as a serum PG I/II ratio of $<3.0$ and a serum PG I level of $<70 \mathrm{ng} / \mathrm{mL}[17]$. Although endoscopic, histological, and serological atrophic gastritis are well correlated, the presence of gastric corpus atrophy is not always consistent with CAG found by endoscopy $[25,26]$. When histological atrophic gastritis progresses, serum PG I levels and the PG I/II ratio are decreased. Similarly, when the extent of atrophy is increased, the serum PG I/II ratio decreases. Moreover, the serum PG I/II ratio is significantly decreased in subjects with severe or moderate CAG than in those with mild CAG [27].

\section{Endoscopic findings of CAG and MG}

Endoscopic changes due to gastric atrophy are consequences of long-term $H$. pylori infection which progress from lesser curvature side of the antrum to greater curvature side of the corpus. Endoscopic findings of
CAG reveal the extent of gastric atrophy by showing an atrophic border consisting of visible transparent vessels (Fig. 4). Endoscopy is a reliable method with high reproducibility which was shown to predict histological atrophy in a multinational study [28]. Gastritis staging, so-called operative link on gastritis assessment (OLGA) staging, provides information on the gastric mucosa by integrating the atrophy score and topography [29]. More recently, the Kyoto Global Consensus Meeting developed a global consensus on the classification of chronic gastritis [30]. It is important to discriminate endoscopic findings based on their characteristics (Fig. 5).

In countries where $H$. pylori infection-related chronic gastritis is common, endoscopic findings or the serum PG assay are often combined to evaluate CAG and MG $[31,32]$. MG exhibits various endoscopic findings such as irregular whitish mucosa, a villous appearance, mucosa with an uneven-surface, and patchy redness. Notably, CAG and/or MG induce spontaneous regression of $\mathrm{H}$. pylori, because it is difficult for the bacterium to survive in the hypoacidic environment produced by severe CAG and/or MG [33-36]. Greater curvature side of the upper corpus seems to be the least atrophic and metaplastic site, and is the location in which $\mathrm{H}$. pylori can survive

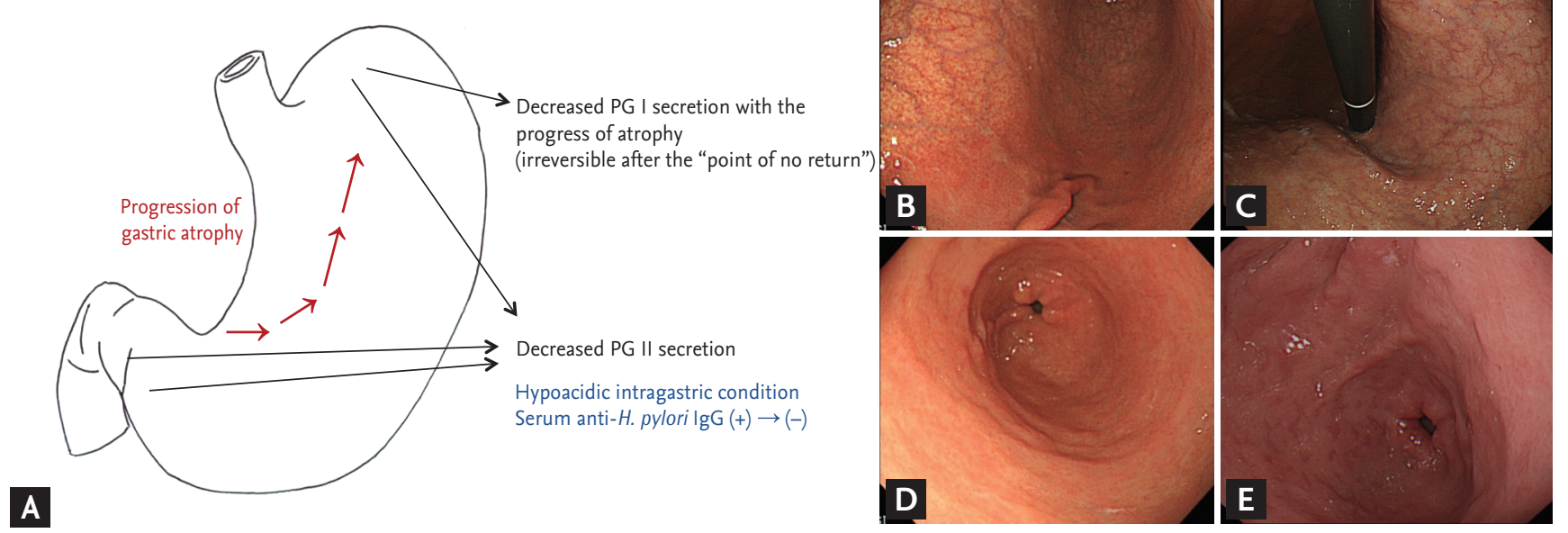

Figure 4. (A) Endoscopic findings in subjects with chronic Helicobacter pylori infection. Therefore, the serum pepsinogen (PG) I level is decreased only when the fundus is damaged by atrophic changes. Based on these findings, gastric corpus atrophy is defined as a serum PG I/II ratio of $<3.0$ and a PG I level of $<70 \mathrm{ng} / \mathrm{mL}$, and is widely used for gastric cancer screening for the detection of high risk individuals. (B) Closed-type atrophic gastritis. Visible transparent vessels can be seen on the anterior-lesser curvature side of the low-body to the angle. An atrophic border is present. (C) Open-type atrophic gastritis. Visible transparent vessels are extended up to the cardia without an atrophic border. (D) Metaplastic gastritis. Multiple large, irregular whitish elevations are present on the distal part of the antrum. This is a common endoscopic finding in subjects with atrophic gastritis on the corpus. (E) Diffuse, irregular whitish changes in metaplastic gastritis. Intestinal metaplasia can have a variety of appearances, such as whitish, nodular elevations. Geographic and hyperemic changes can be also found in metaplastic gastritis. 
for the longest period of time before spontaneous regression.

\section{Increased risk of intestinal-type gastric cancer and dysplasia}

Endoscopic and serologic findings of CAG and MG are good tools for predicting the risk of gastric carcinogenesis [37]. Subjects with a low PG I/II ratio are at an increased risk for intestinal-type gastric cancer and dysplasia [38]. One study showed the significance of the topography of histologic gastritis as a marker to identify individuals at high risk for gastric cancer; pangastritis put patients at the highest risk, followed by corpus-predominant gastritis and antrum-predominant gastritis [39]. Furthermore, MG is also a predictive marker for intestinal-type gastric cancer [40]. A study showed that IM on greater curvature side of the corpus, along with a decreased serum PG I level, indicates a high risk of intestinal-type gastric cancer and dysplasia [41].

\section{STOMACH WITH PAST H. PYLORI INFECTION}

The ability of gastric mucosa cells to heal from an $\mathrm{H}$. pylori infection depends on the period of bacterial regression. If $H$. pylori is eradicated before the point of no return, gastric mucosa regains its secreting ability, and serum PG concentrations start to increase (Fig. 6). This is rare in cases of spontaneous regression of $\mathrm{H}$. pylori infection, in which most damage to the gastric mucosa is irreversible.

\section{Infections eradicated at a reversible stage}

A long-term follow-up study showed that the changes induced by mild CAG and CSG are reversible, in both histological and serological findings [42]. The degrees of inflammation and activity, and lymphoid follicle infiltration decrease after H. pylori eradication [43]. Serum PG II is a good marker of intragastric environmental changes before and after $\mathrm{H}$. pylori eradication [44].

Notably, even severe gastric atrophy and IM are reversible in some patients [45]. It has been reported that some cases of MG and corpus-predominant gastritis with a low serum PG I/II ratio were reversible $[46,47]$. On the contrary, no significant changes were found in the molecular alterations related to carcinogenesis even after $H$. pylori eradication [48].

\section{Infections eradicated at an irreversible stage}

The cancer risk after eradication depends on the extent of CAG before eradication, and is highly correlated with the severity of corpus atrophy [49,50]. In subjects with irreversible damage to the gastric mucosa, serum PG I levels and PG I/II ratio continue to decrease. Therefore, periodic endoscopic screening is required [51]. Nevertheless, only $5 \%$ of patients with severe CAG develop intestinal-type gastric cancer [52]. There is no consensus in Korea on the role of eradication in the prevention of gastric cancer [53-55], but endoscopic screening is recommended for these subjects, as it is for Korean Americans with known CAG, IM, or a family history of gastric cancer [56].
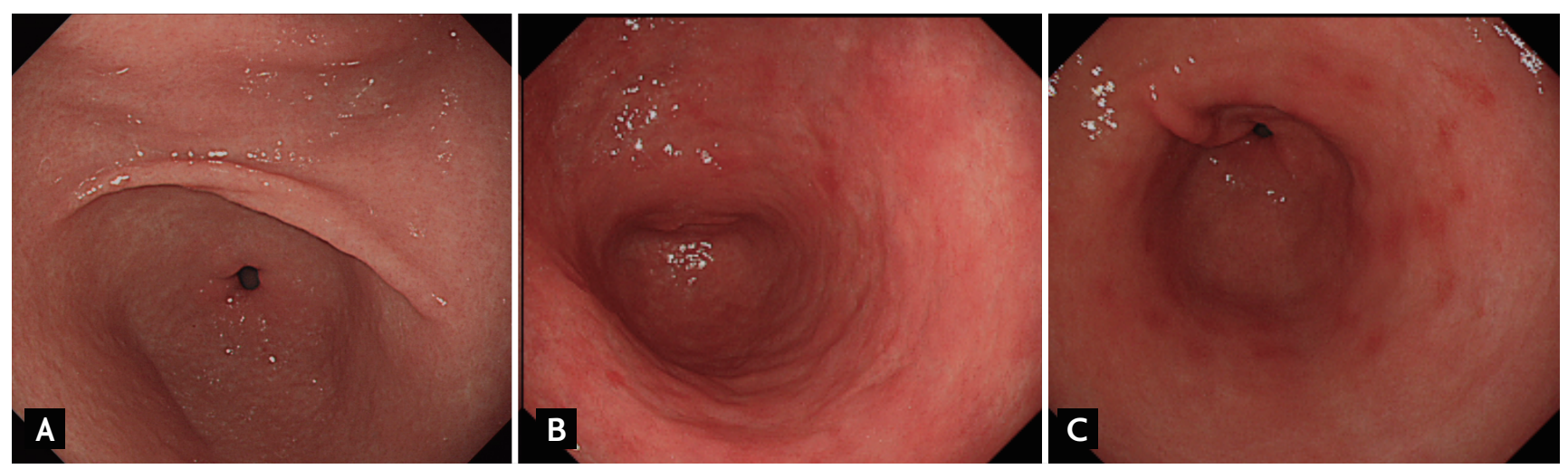

Figure 5. Different endoscopic findings of nodular gastritis, metaplastic gastritis, and erosive gastritis. (A) Nodular gastritis. On the distal part of the antrum, multiple elevated nodules are seen without color change. The nodules are regular in size and shape. (B) Metaplastic gastritis. Intestinal metaplasia can be confused when hyperemic mucosa is augmented by whitish surrounding mucosa. The elevations are irregular in size, shape, and color. (C) Erosive gastritis. Elevated hyperemic erosions are scattered on the antrum. 


\section{Spontaneous regression of $\mathrm{H}$. pylori}

Spontaneous regression occurs in the most severe, late stages of gastric atrophy and/or IM when the stomach environment is inhospitable for $\mathrm{H}$. pylori growth [57]. In such advanced conditions, the serum anti-H. pylori immunoglobulin $\mathrm{G}(\mathrm{IgG})$ assay reverts to a negative finding [58]. This indicates hypoacidity of the stomach, and also provides a rationale for measuring serum PG levels as a secondary means of gastric cancer screening [59]. Sub-
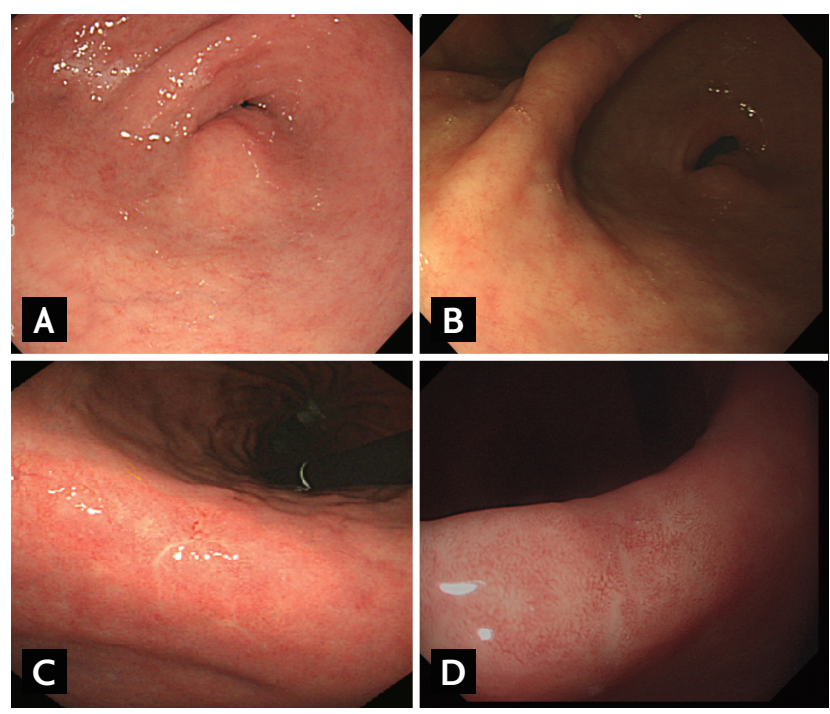

Figure 6. Different prognoses in two Helicobacter pylori-infected subjects. (A) Endoscopic findings of a 55-year-old man. A single, raised erosion is present on the greater curvature side of the pylorus. A serum anti-H. pylori immunoglobulin $\mathrm{G}(\mathrm{IgG})$ assay was positive on the day of endoscopic examination. The serum pepsinogen (PG) I level was $25.8 \mathrm{ng} / \mathrm{mL}$, the PG II level was $12.2 \mathrm{ng} / \mathrm{mL}$, and the PG I/II ratio was 2.1 (normal values: PG I > 70.0 ng/mL, PG II < 15.0 ng/mL, PG I/ II ratio $>3.0$ ). Pathology test results revealed chronic gastritis with marked intestinal metaplasia, and Giemsa staining was negative. (B) Forty-three months after the initial tests. The patient revisited our clinic for follow-up testing. The serum anti-H. pylori IgG assay was still positive, and the serum PG I level and PG I/II ratio had decreased (PG I 24.0 ng/mL, PG II 13.0 ng/mL, PG I/II ratio 1.8). Pathology test results and Giemsa staining were not altered. (C) Endoscopic findings of a 62-year-old man. The serum anti-H. pylori IgG assay was positive, and the serum PG assay finding was also positive (PG I $28.6 \mathrm{ng} / \mathrm{mL}$, PG II 14.5 ng/mL, PG I/II ratio 2.0). Active gastritis with foveolar hyperplasia and regenerated glands were found on the biopsy, and Giemsa staining was positive. (D) Follow-up endoscopy 1 year after successful $H$. pylori eradication. The serum anti-H. pylori IgG test became negative, and the serum PG I/II ratio had increased (PG I 29.0 ng/mL, PG II 10.4 ng/mL, PG I/II ratio 2.7). Pathology test results revealed chronic gastritis without $H$. pylori-like microorganisms, and Giemsa staining was negative. jects with gastric corpus atrophy and low $H$. pylori concentration show the most impaired acid secretion and the highest risk of intestinal-type gastric cancer. Taken together, the greatest risk for intestinal-type gastric cancer is found in seronegative subjects with past infections and low PG I/II ratios [60-62].

\section{CONCLUSIONS}

Endoscopic gastritis reflects the excretion ability of the gastric mucosa and indicates whether the intragastric conditions are hypoacidic or hyperacidic. Nodularity, multiple hemorrhagic spots, and thickened gastric folds indicate active $H$. pylori infection, while atrophy and metaplasia indicate chronic inactive $\mathrm{H}$. pylori infection. Antacids are helpful in the treatment of subjects with hyperacidic stomachs and increased serum PG levels, but not in those with hypoacidic stomachs and decreased PG levels. The risk of diffuse-type gastric cancer is highest in subjects with active infections, increased serum PG II concentrations, and endoscopic findings indicating nodular gastritis, hemorrhagic spots, and hypertrophic gastric rugae. On the contrary, the risk of intestinal-type gastric cancer is highest in subjects with chronic inactive infections, decreased serum PG I concentrations, and endoscopic findings of CAG and MG. By understanding serum PG assay findings and typical endoscopic gastritis findings of infected and noninfected stomachs, physicians will be able to identify the subjects who would benefit from taking acid suppressants with or without $H$. pylori eradication. Prevention of gastric cancer will be maximized when both serologic and endoscopic findings can be utilized as secondary measures, along with $\mathrm{H}$. pylori eradication as a primary prevention.

\section{Conflict of interest}

No potential conflict of interest relevant to this article was reported.

\section{Acknowledgments}

This work was supported by Konkuk University in 2016. 


\section{REFERENCES}

1. Chu S, Schubert ML. Gastric secretion. Curr Opin Gastroenterol 2012;28:587-593.

2. Ghosh T, Lewis DI, Axon AT, Everett SM. Review article: methods of measuring gastric acid secretion. Aliment Pharmacol Ther 2011;33:768-781.

3. Sipponen P, Graham DY. Importance of atrophic gastritis in diagnostics and prevention of gastric cancer: application of plasma biomarkers. Scand J Gastroenterol 2007;42:2-10.

4. Rehfeld JF, Bardram L, Hilsted L, Poitras P, Goetze JP. Pitfalls in diagnostic gastrin measurements. Clin Chem 2012;58:831-836.

5. Miki K. Gastric cancer screening using the serum pepsinogen test method. Gastric Cancer 2006;9:245-253.

6. Park HK, Kim N, Lee SW, et al. The distribution of endoscopic gastritis in 25,536 heath check-up subjects in Korea. Korean J Helicobacter Up Gastrointest Res 2012;12:237-243.

7. Yoon H, Kim N, Lee HS, et al. Helicobacter pylori-negative gastric cancer in South Korea: incidence and clinicopathologic characteristics. Helicobacter 2011;16:382-388.

8. Toh BH. Diagnosis and classification of autoimmune gastritis. Autoimmun Rev 2014;13:459-462.

9. Reed C, Woosley JT, Dellon ES. Clinical characteristics, treatment outcomes, and resource utilization in children and adults with eosinophilic gastroenteritis. Dig Liver Dis 2015;47:197-201.

10. Hayashi S, Imamura J, Kimura K, Saeki S, Hishima T. Endoscopic features of lymphoid follicles in Helicobacter pylori-associated chronic gastritis. Dig Endosc 2015;27:53-60.

11. Lee OJ, Lee EJ, Kim HJ. Correlations among gastric juice $\mathrm{pH}$ and ammonia, Helicobacter pylori infection and gastric mucosal histology. Korean J Intern Med 2004;19:205-212.

12. Kitamura Y, Yoshihara M, Ito M, et al. Diagnosis of Helicobacter pylori-induced gastritis by serum pepsinogen levels. J Gastroenterol Hepatol 2015;30:1473-1477.

13. Di Mario F, Cavallaro LG, Moussa AM, et al. Usefulness of serum pepsinogens in Helicobacter pylori chronic gastritis: relationship with inflammation, activity, and density of the bacterium. Dig Dis Sci 2006;51:1791-1795.

14. Kitamura S, Yasuda M, Muguruma N, et al. Prevalence and characteristics of nodular gastritis in Japanese elderly. J Gastroenterol Hepatol 2013;28:1154-116o.

15. Yoshida T, Kato J, Inoue I, et al. Cancer development based on chronic active gastritis and resulting gastric atrophy as assessed by serum levels of pepsinogen and Helicobacter pylori antibody titer. Int J Cancer 2014;134:1445-1457.

16. Choi HS, Lee SY, Kim JH, et al. Combining the serum pepsinogen level and Helicobacter pylori antibody test for predicting the histology of gastric neoplasm. J Dig Dis 2014;15:293-298.

17. Bornschein J, Selgrad M, Wex T, Kuester D, Malfertheiner P. Serological assessment of gastric mucosal atrophy in gastric cancer. BMC Gastroenterol 2012;12:10.

18. Lee SY. Future candidates for indications of Helicobacter pylori eradication: do the indications need to be revised? J Gastroenterol Hepatol 2012;27:200-211.

19. Asaka M, Mabe K, Matsushima R, Tsuda M. Helicobacter pylori eradication to eliminate gastric cancer: the Japanese Strategy. Gastroenterol Clin North Am 2015;44:639-648.

20. Ahn SY, Lee SY, Hong SN, et al. Endoscopic diagnosis of open-type atrophic gastritis is related to the histological diagnosis of intestinal metaplasia and Cdx2 expression. Dig Dis Sci 2011;56:1119-1126.

21. Testoni PA, Bonassi U, Bagnolo F, Colombo E, Scelsi R. In diffuse atrophic gastritis, routine histology underestimates Helicobacter pylori infection. J Clin Gastroenterol 2002;35:234-239.

22. Korstanje A, van Eeden S, Offerhaus JA, et al. Comparison between serology and histology in the diagnosis of advanced gastric body atrophy: a study in a Dutch primary community. J Clin Gastroenterol 2008;42:18-22.

23. Derakhshan MH, El-Omar E, Oien K, et al. Gastric histology, serological markers and age as predictors of gastric acid secretion in patients infected with Helicobacter pylori. J Clin Pathol 2006;59:1293-1299.

24. Kim DH, Kim GH, Kim JY, et al. Endoscopic grading of atrophic gastritis is inversely associated with gastroesophageal reflux and gastropharyngeal reflux. Korean J Intern Med 2007;22:231-236.

25. Lee JY, Kim N, Lee HS, et al. Correlations among endoscopic, histologic and serologic diagnoses for the assessment of atrophic gastritis. J Cancer Prev 2014;19:47-55.

26. Takao T, Ishikawa T, Ando T, et al. Multifaceted assessment of chronic gastritis: a study of correlations between serological, endoscopic, and histological diagnostics. Gastroenterol Res Pract 2011;2011:631461.

27. Yang JH, Lee SY, Hong SN, et al. Changing trends of serum pepsinogen $\mathrm{I} / \mathrm{II}$ ratio in asymptomatic subjects. Korean J Helicobacter Up Gastrointest Res 2012;12:96-102.

28. Kono S, Gotoda T, Yoshida S, et al. Can endoscopic at- 
rophy predict histological atrophy? Historical study in United Kingdom and Japan. World J Gastroenterol 2015;21:13113-13123.

29. Rugge M, Meggio A, Pennelli G, et al. Gastritis staging in clinical practice: the OLGA staging system. Gut 2007;56:631-636.

30. Sugano K, Tack J, Kuipers EJ, et al. Kyoto global consensus report on Helicobacter pylori gastritis. Gut 2015;64:1353-1367.

31. Song HJ, Jang SJ, Yun SC, et al. Low levels of pepsinogen I and pepsinogen I/II ratio are valuable serologic markers for predicting extensive gastric corpus atrophy in patients undergoing endoscopic mucosectomy. Gut Liver 2010;4:475-480.

32. Nomura S, Ida K, Terao S, et al. Endoscopic diagnosis of gastric mucosal atrophy: multicenter prospective study. Dig Endosc 2014;26:709-719.

33. Storskrubb T, Aro P, Ronkainen J, et al. A negative Helicobacter pylori serology test is more reliable for exclusion of premalignant gastric conditions than a negative test for current $H$. pylori infection: a report on histology and $H$. pylori detection in the general adult population. Scand J Gastroenterol 2005;40:302-311.

34. Kang HY, Kim N, Park YS, et al. Progression of atrophic gastritis and intestinal metaplasia drives Helicobacter pylori out of the gastric mucosa. Dig Dis Sci 2006;51:2310-2315.

35. Yoo JY, Kim N, Park YS, et al. Detection rate of Helicobacter pylori against a background of atrophic gastritis and/or intestinal metaplasia. J Clin Gastroenterol 2007;41:751-755.

36. Kim CG, Choi IJ, Lee JY, et al. Biopsy site for detecting Helicobacter pylori infection in patients with gastric cancer. J Gastroenterol Hepatol 2009;24:469-474.

37. Masuyama H, Yoshitake N, Sasai T, et al. Relationship between the degree of endoscopic atrophy of the gastric mucosa and carcinogenic risk. Digestion 2015;91:30-36.

38. Yanaoka K, Oka M, Mukoubayashi C, et al. Cancer high-risk subjects identified by serum pepsinogen tests: outcomes after 10-year follow-up in asymptomatic middle-aged males. Cancer Epidemiol Biomarkers Prev 2008;17:838-845.

39. Imagawa $\mathrm{S}$, Yoshihara $\mathrm{M}$, Ito $\mathrm{M}$, et al. Evaluation of gastric cancer risk using topography of histological gastritis: a large-scaled cross-sectional study. Dig Dis Sci 2008;53:1818-1823.

40. Shichijo S, Hirata Y, Sakitani K, et al. Distribution of intestinal metaplasia as a predictor of gastric cancer development. J Gastroenterol Hepatol 2015;30:1260-1264.
41. Shiotani A, Iishi H, Uedo N, et al. Histologic and serum risk markers for noncardia early gastric cancer. Int J Cancer 2005;115:463-469.

42. Ohkusa T, Miwa H, Nomura $\mathrm{T}$, et al. Improvement in serum pepsinogens and gastrin in long-term monitoring after eradication of Helicobacter pylori: comparison with $\mathrm{H}$. pylori-negative patients. Aliment Pharmacol Ther 2004;20 Suppl 1:25-32.

43. Pimanov SI, Makarenko EV, Voropaeva AV, Matveenko ME, Voropaev EV. Helicobacter pylori eradication improves gastric histology and decreases serum gastrin, pepsinogen I and pepsinogen II levels in patients with duodenal ulcer. J Gastroenterol Hepatol 2008;23:16661671.

44. Massarrat S, Haj-Sheykholeslami A, Mohamadkhani A, et al. Pepsinogen II can be a potential surrogate marker of morphological changes in corpus before and after $\mathrm{H}$. pylori eradication. Biomed Res Int 2014;2014:481607.

45. Ito M, Haruma K, Kamada T, et al. Helicobacter pylori eradication therapy improves atrophic gastritis and intestinal metaplasia: a 5-year prospective study of patients with atrophic gastritis. Aliment Pharmacol Ther 2002;16:1449-1456.

46. Kokkola A, Sipponen P, Rautelin H, et al. The effect of Helicobacter pylori eradication on the natural course of atrophic gastritis with dysplasia. Aliment Pharmacol Ther 2002;16:515-520.

47. Kang JM, Kim N, Shin CM, et al. Predictive factors for improvement of atrophic gastritis and intestinal metaplasia after Helicobacter pylori eradication: a three-year follow-up study in Korea. Helicobacter 2012;17:86-95.

48. Kawanaka M, Watari J, Kamiya N, et al. Effects of Helicobacter pylori eradication on the development of metachronous gastric cancer after endoscopic treatment: analysis of molecular alterations by a randomised controlled trial. Br J Cancer 2016;114:21-29.

49. Yanaoka K, Oka M, Ohata H, et al. Eradication of Helicobacter pylori prevents cancer development in subjects with mild gastric atrophy identified by serum pepsinogen levels. Int J Cancer 2009;125:2697-2703.

50. Shiotani A, Uedo N, Iishi H, et al. Predictive factors for metachronous gastric cancer in high-risk patients after successful Helicobacter pylori eradication. Digestion 2008;78:113-119.

51. Miki K, Fujishiro M, Kodashima S, Yahagi N. Longterm results of gastric cancer screening using the serum 
pepsinogen test method among an asymptomatic middle-aged Japanese population. Dig Endosc 2009;21:78-81.

52. Venerito M, Malfertheiner P. Preneoplastic conditions in the stomach: always a point of no return? Dig Dis 2015;33:510.

53. Choi IJ. Current evidence of effects of Helicobacter pylori eradication on prevention of gastric cancer. Korean J Intern Med 2013;28:525-537.

54. Bang CS, Baik GH. Time to learn from the past and prepare for the future in Helicobacter pylori eradication. Korean J Intern Med 2015;30:789-791.

55. Graham DY. Roadmap for elimination of gastric cancer in Korea. Korean J Intern Med 2015;30:133-139.

56. Kim GH, Bang SJ, Ende AR, Hwang JH. Is screening and surveillance for early detection of gastric cancer needed in Korean Americans? Korean J Intern Med 2015;30:747-758.

57. Kokkola A, Kosunen TU, Puolakkainen P, et al. Spontaneous disappearance of Helicobacter pylori antibodies in patients with advanced atrophic corpus gastritis. APMIS 2003;111:619-624.

58. Camorlinga-Ponce M, Flores-Luna L, Lazcano-Ponce E, et al. Age and severity of mucosal lesions influence the performance of serologic markers in Helicobacter pylori-associated gastroduodenal pathologies. Cancer Epidemiol Biomarkers Prev 2008;17:2498-2504.

59. Kishikawa $\mathrm{H}$, Nishida J, Ichikawa $\mathrm{H}$, et al. Fasting gastric $\mathrm{pH}$ of Japanese subjects stratified by IgG concentration against Helicobacter pylori and pepsinogen status. Helicobacter 2011;16:427-433.

6o. Watabe H, Mitsushima T, Yamaji Y, et al. Predicting the development of gastric cancer from combining Helicobacter pylori antibodies and serum pepsinogen status: a prospective endoscopic cohort study. Gut 2005;54:764-768.

61. Zhang X, Xue L, Xing L, et al. Low serum pepsinogen I and pepsinogen $\mathrm{I} / \mathrm{II}$ ratio and Helicobacter pylori infection are associated with increased risk of gastric cancer: 14-year follow up result in a rural Chinese community. Int J Cancer 2012;130:1614-1619.

62. Mizuno S, Miki I, Ishida T, et al. Prescreening of a highrisk group for gastric cancer by serologically determined Helicobacter pylori infection and atrophic gastritis. Dig Dis Sci 2010;55:3132-3137. 